\title{
STUDI PENGOLAHAN TERIPANG KERING
}

\author{
Oleh \\ Nurlaila Ervina Herliany ${ }^{1 *}$, Eko Nofridiansyah ${ }^{1}$, Bayu Sasongko ${ }^{1}$ \\ ${ }^{1}$ Program Studi Ilmu Kelautan Fakultas Pertanian Universitas Bengkulu, Bengkulu \\ Email : vivien.unib@gmail.com \\ Received July 2016, Accepted August 2016
}

\begin{abstract}
Sea cucumbers is fisheries commodities that have high prices and for a long time ago have been used as natural medicine. In the world market, sea cucumbers sell as dried sea cucumbers (beche-de-mer). Indonesia is the biggest exporter of dried sea cucumbers in the world. Unfortunately, the selling prices was lower than other countries because of the poor quality (caused by bad processing). The aim of this study is to learn about dried sea cucumbers's processing and determine its quality. Sand sea cucumbers (Holothuria scabra) was used as the object of this research. Processing of dried sea cucumbers based on modified method of Sasongko (2015). Dried sea cucumbers then analyze for proximate contents (water, ash and protein content) and compares it with SNI . The result shows that dried sea cucumbers have a good quality, based on visual looks and proximate contents. Water content of dried sea cucumbers is $7,3 \%$; ash content $9,8 \%$ and protein content $79,59 \%$ with rock hard's texture and dark colour.
\end{abstract}

keywords : quality, processing, dried sea cucumbers

\begin{abstract}
ABSTRAK
Teripang merupakan komoditas perikanan bernilai ekonomis tinggi dan telah digunakan sejak lama sebagai obat-obatan alami. Di pasar dunia, umumnya teripang dipasarkan dalam bentuk kering. Indonesia merupakan negara pengekspor teripang terbesar di dunia. Tetapi, nilai jualnya lebih rendah dibanding negara lain karena mutu yang rendah sebagai hasil proses pengolahan yang kurang baik. Untuk itu, perlu dilakukan studi mengenai proses pengolahan teripang kering. Tujuan dari penelitian ini adalah untuk mempelajari proses pengolahan teripang kering serta menentukan mutu teripang kering yang dihasilkan. Teripang segar yang digunakan adalah jenis teripang pasir (Holothuria scabra). Proses pengolahan mengacu pada metode Sasongko (2015) yang dimodifikasi. Teripang kering yang dihasilkan dianalisis proksimat (kadar air, abu dan protein) dan hasilnya dibandingkan dengan SNI. Hasil penelitian menunjukkan bahwa teripang kering memiliki kualitas yang bagus, dilihat dari kenampakan visual dan kandungan proksimatnya. Kadar air teripang kering 7,3\%; kadar abu 9,8\% dan kadar protein 79,59\% dengan tekstur yang keras seperti batu dan warna hitam merata.
\end{abstract}

kata kunci : mutu, pengolahan, teripang kering 


\section{PENDAHULUAN}

\section{Latar Belakang}

Teripang (Holothuroidea) merupakan salah satu komoditas perikanan yang bernilai ekonomis tinggi dan sangat digemari di pasar internasional. Biota laut ini telah digunakan sejak lama oleh bangsa Cina sebagai obat-obatan alami karena dipercaya dapat memperkaya darah, mengobati penyakit ginjal dan organ reproduksi. Ditambahkan pula bahwa teripang diyakini dapat mengobati kelumpuhan, impotensi, konstipasi dan sering buang air kecil (Subaldo, 2011).

Pemanfaatan teripang dalam bidang farmasi disebabkan karena teripang mengandung berbagai bahan aktif yang bermanfaat. Berbagai penelitian telah dilakukan untuk mengetahui manfaat teripang dalam bidang kesehatan. Wibowo dan Yunizal (1997) menyatakan bahwa teripang mengandung senyawa antioksidan yang berfungsi mengurangi kerusakan sel jaringan tubuh. Farouk dkk. (2007) menambahkan bahwa ekstrak teripang menunjukkan aktifitas antiprotozoa dan menghambat sel tumor, serta dapat digunakan sebagai penyembuh luka dan antitrombotik (mengurangi pembekuan darah di dalam saluran darah) sehingga dapat mengurangi resiko penyakit jantung dan stroke.

Indonesia merupakan salah satu negara pengekspor teripang terbesar di dunia. Berdasarkan data Brown $d k k$. (2010), Indonesia menempati urutan pertama dari 38 negara pengekspor teripang di dunia dengan persentase sebesar $12 \%$ dari total ekspor. Sebagian besar produk olahan teripang dari Indonesia diekspor dalam bentuk teripang kering maupun teripang asap.

Menurut Duan dkk. (2007), sebagian besar teripang kering diolah dengan cara tradisional, yang meliputi penggaraman, perebusan berulang-ulang dan pengeringan di bawah sinar matahari selama 2-3 hari. Metode tradisional seperti ini yang juga umumnya diterapkan di Indonesia. Kelemahan metode tradisional adalah memakan waktu yang cukup lama karena tingkat ketergantungan yang tinggi terhadap cuaca dalam proses pengeringan. Selain itu, belum ada prosedur baku dalam pengolahan secara tradisional sehingga memungkinkan hasil yang diperoleh tidak seragam kualitasnya. Akibatnya nilai ekspor teripang kering dari Indonesia memiliki harga yang cukup rendah dibandingkan dengan negaranegara lain (Conand (1990) dan Krishnasamy (1991) dalam Hutomo (1997)).

Untuk meningkatkan harga jual teripang kering, maka perlu ditingkatkan mutu teripang yang dihasilkan. Salah satu caranya adalah dengan memodifikasi proses pengolahan teripang agar diperoleh metode pengolahan yang lebih baik dan menghasilkan mutu yang seragam. Untuk itu, perlu dilakukan studi mengenai proses pengolahan teripang kering..

\section{Tujuan}

Tujuan dari penelitian ini adalah untuk mempelajari proses pengolahan teripang kering serta menentukan mutu teripang kering yang dihasilkan sehingga dapat dipergunakan sebagai bahan informasi mengenai pengolahan teripang kering yang baik.

\section{METODE PENELITIAN}

Penelitian ini dilaksanakan di Kelurahan Pagar Dewa, Kecamatan Selebar, Kota Bengkulu pada bulan Desember 2014. Analisis proksimat sampel teripang kering dilakukan di Laboratorium Kimia, Fakultas MIPA, Universitas Bengkulu. Teripang yang digunakan sebagai bahan penelitian adalah teripang pasir (Holothuria scabra) dengan berat antara 400-600 gram yang diperoleh dari perairan Pulau Baai, Kota Bengkulu. 
Metode pengolahan teripang kering mengacu pada metode Sasongko (2015) yang dimodifikasi. Teripang terlebih dahulu dikeluarkan isi perutnya dengan cara digunting di bagian anus selebar $1 \mathrm{~cm}$, kemudian ditekan dengan kuat pada bagian perutnya agar seluruh isi perut keluar. Teripang selanjutnya dicuci menggunakan air bersih dan direbus. Perebusan dilakukan sebanyak tiga kali. Perebusan pertama pada suhu $60 \pm 5^{\circ} \mathrm{C}$ selama 30 menit dengan campuran daun pepaya cincang. Perebusan kedua dilakukan pada air mendidih selama 60 menit, juga dicampur dengan daun pepaya cincang. Setelah perebusan kedua, dilakukan penghilangan lapisan kapur yang ada di permukaan tubuh teripang dengan cara disikat menggunakan sikat halus. Kemudian dilanjutkan dengan perebusan ketiga dengan campuran bumbu-bumbu (kunyit, daun salam, laos, jahe, sereh) pada suhu $50 \pm 5^{\circ} \mathrm{C}$ selama 20 menit. Setiap tahapan perebusan diikuti dengan proses pendinginan dengan cara diangin-anginkan sebelum teripang diproses ke tahap selanjutnya. Tahap terakhir yaitu pengeringan teripang menggunakan oven dengan suhu $60^{\circ} \mathrm{C}$ selama \pm 14 jam hingga kadar air teripang kurang dari $11 \%$.

Teripang kering yang dihasilkan dianalisis proksimat, meliputi kadar air (SNI 01-2356-1991), abu (SNI 01-2354-1991), dan protein (SNI 01-2365-1991), kemudian hasilnya dibandingkan dengan Standar Nasional Indonesia (SNI) untuk teripang kering (SPI-kan/02/29/1987).

\section{HASIL DAN PEMBAHASAN}

\section{Pengolahan Teripang Kering}

Mutu teripang kering yang dihasilkan selain ditentukan oleh proses pengolahan yang dilakukan juga ditentukan oleh kualitas bahan baku yang digunakan. Bahan baku teripang segar yang digunakan diusahakan masih dalam keadaan hidup sebelum diolah menjadi teripang kering dan tidak memiliki kerusakan fisik (luka pada bagian tubuh). Penggunaan teripang hidup dimaksudkan agar tidak terjadi penurunan mutu produk teripang kering karena teripang merupakan hasil perikanan yang mudah mengalami kerusakan (highly perishable food). Teripang segar dengan kerusakan fisik juga harus dihindari karena dapat berpotensi untuk menimbulkan stres pada teripang sehingga daya tahan tubuhnya menurun dan mudah mengalami kematian saat proses handling sebelum pengolahan dilakukan.

\section{Pengeluaran isi perut}

Teripang segar yang siap diolah, terlebih dahulu dikeluarkan isi perutnya. Pengeluaran isi perut bertujuan untuk menghindari proses pembusukan pada teripang karena pada isi perut mengadung mikroorganisme yang dapat menyebabkan kebusukan pada teripang. Proses pembusukan yang terjadi ditandai dengan munculnya bau tidak sedap (off odor) dan hilangnya kelenturan daging teripang sehingga teripang menjadi lembek serta tidak kenyal. Aktivitas mikroba dapat menyebabkan kerusakan komponen penyusun jaringan pengikat dan benang-benang daging udang sehingga kehilangan kekuatan untuk menopang struktur daging agar kompak. Kerusakan struktur jaringan daging akan menyebabkan daging kehilangan sifat kelenturannya dan kekenyalannya sehingga menjadi lunak (Hadiwiyoto, 1993).

Pengeluaran isi perut umumnya secara tradisional dilakukan dengan cara membelah bagian perut (ventral) teripang, dimulai dari anus hingga mulut (sepanjang tubuh teripang). Tetapi pada penelitian ini, pengeluaran isi perut dilakukan dengan cara menggunting sepanjang $1 \mathrm{~cm}$ pada bagian anus. Hal ini 
dilakukan untuk meminimalkan bekas sayatan yang tampak pada produk teripang kering. Menurut Purcell (2014), konsumen berdarah Asia yang merupakan konsumen utama produk teripang kering, lebih menyukai teripang kering dengan sedikit sayatan pada bagian tubuhnya. SNI 01-2346-2006 juga menentukan kriteria teripang kering yang baik adalah jika bekas belahan tertutup baik (bekas sayatan tidak tampak).

Teripang yang telah dikeluarkan isi perutnya kemudian dicuci bersih untuk menghilangkan kotoran yang melekat pada tubuh teripang. Pencucian juga dilakukan pada bagian dalam tubuh teripang, agar sisa isi perut benar-benar bersih. Pencucian dilakukan menggunakan air yang bersih untuk menjada higienitas produk yang dihasilkan.

\section{Perebusan}

Perebusan merupakan salah satu metode pengolahan tradisional yang bertujuan untuk memperpanjang masa simpan suatu produk. Perebusan yang menggunakan suhu tinggi diharapkan dapat membunuh mikroorganisme pada produk pangan yang dapat mempercepat proses pembusukan makanan. Pada pengolahan teripang kering, perebusan dilakukan sebanyak tiga kali. Perebusan pertama dilakukan pada suhu tidak terlalu tinggi $\left(60 \pm 5^{\circ} \mathrm{C}\right)$. Hal ini dilakukan agar kulit teripang tidak mengalami kerusakan. Menurut Purcell (2014), lonjakan suhu yang tinggi dapat menyebabkan kerusakan kulit teripang yang nantinya mempengaruhi kenampakan produk akhir teripang yang dihasilkan. Hutomo (1997) menyatakan bahwa perebusan pertama ini bertujuan untuk memperoleh tekstur yang kenyal pada teripang sehingga memudahkan dalam proses pembersihan kulit teripang. Sasongko (2015) menambahkan bahwa perebusan pertama juga bermanfaat untuk membantu penghilangan lapisan kapur pada kulit teripang karena adanya campuran daun pepaya.

Perebusan kedua dilakukan menggunakan air mendidih dan daun pepaya cincang selama 60 menit. Penggunaan suhu yang lebih tinggi dalam waktu lama bertujuan agar mikroorganisme yang tahan terhadap suhu tinggi dapat mati sehingga proses pembusukan tidak terjadi. Daun pepaya yang digunakan bermanfaat untuk mempermudah proses penghilangan lapisan kapur pada kulit teripang. Kulit luar teripang pasir terdiri atas suatu lapisan yang melekat kuat dan terasa kasar dengan rangka berbentuk jarum atau keeping-keping kecil yang berkapur dan menyebar dalam jaringan tubuh (Tanikawa, 1971). Penghilangan lapisan kapur secara tradisional menggunakan daun papaya, buah papaya atau daun gadung. Ketiga bahan tersebut diketahui mengandung enzim papain yang berfungsi untuk mempermudah penghilangan lapisan kapur pada kulit teripang.

Papain merupakan enzim proteolitik yang aktivitasnya dapat menghidrolisis protein kolagen pada kulit teripang. Enzim ini akan memecah sebagian besar ikatan peptide asam amino prolin dan hidroksi prolin yang terdapat pada kolagen sehingga kekuatan jaringan sel pada kulit mengalami pelunakan (Sofia, 1992). Hal ini berakibat pada terlepasnya lapisan kapur pada kulit teripang (Sudrajat, 2002). Setelah perebusan selesai, kulit teripang dibersihkan dengan sikat secara hati-hati untuk melepaskan lapisan kapur dari kulit teripang secara menyeluruh. Teripang kering yang bernilai jual tinggi jika permukaan kulitnya berwarna gelap sempurna (tidak terdapat bintik-bintik putih yang menandakan masih terdapat lapisan kapur pada permukaan tubuhnya). Tanikawa (1971) menegaskan bahwa apabila pada permukaan kulit teripang kering masih banyak dijumpai kapur maka produknya digolongkan sebagai produk yang bermutu rendah.

Perebusan terakhir dilakukan dengan campuran bumbu-bumbu. Perebusan ketiga ini bertujuan untuk memaksimalkan proses pengeluaran air dari tubuh teripang sehingga proses pengeringan dapat lebih cepat (Hutomo, 1997). 
Penggunaan bumbu-bumbu dimaksudkan agar bau amis pada teripang dapat diminimalisir untuk menambah daya tarik konsumen.

\section{Pengeringan}

Tahap terakhir adalah proses pengeringan. Proses pengeringan secara tradisional dilakukan dengan cara dijemur di bawah sinar matahari dengan lama penjemuran bervariasi, tergantung pada cuaca dan ukuran teripang yang dikeringkan. Hal ini dapat merugikan jika cuaca tidak mendukung, sehingga proses pengeringan teripang menjadi terhambat dan dapat menimbulkan kerusakan (busuk) pada teripang jika proses pengeringan terlalu lama. Pada penelitian ini, teripang dikeringkan dengan oven pada suhu $60^{\circ} \mathrm{C}$ selama \pm 14 jam. Penggunaan oven dilakukan agar proses pengeringan tidak tergantung dengan cuaca dan panas yang didapatkan konstan sehingga proses pengeringan menjadi lebih cepat dan dapat dikontrol. Suhu yang digunakan pada saat pengeringan tidak terlalu tinggi agar teripang dapat kering dengan baik pada bagian luar dan dalam. Suhu yang terlalu tinggi menyebabkan bagian luar akan cepat kering sementara bagian dalam belum kering sehingga bentuk teripang menjadi tidak lurus (melingkar) (Purcell, 2014).

Pengeringan bertujuan untuk menghilangkan kadar air pada teripang hingga titik minimal sehingga teripang dapat disimpan dalam waktu lama. Jumlah kandungan air pada suatu produk akan mempengaruhi daya tahan bahan tersebut terhadap serangan mikroba (Adawiyah, 2007). Produk dengan kadar air tinggi rentan terhadap serangan mikroba sehingga lebih cepat mengalami kemunduran mutu (Herliany, 2011). Beberapa keuntungan dari pengeringan diantaranya yaitu bahan menjadi lebih awet dengan volume ukuran bahan menjadi lebih kecil sehingga mempermudah dan menghemat ruang pengangkutan dan pengepakan, dengan demikian diharapkan biaya produksi menjadi lebih murah (Winarno $d k k$., 1980). Pengeringan teripang harus dilakukan hingga teripang berubah teksturnya menjadi keras seperti batu. Tekstur yang keras ini akan mencegah timbulnya jamur selama masa penyimpanan teripang kering (Purcell, 2014). Menurut Sasongko (2015), proses pengeringan dapat mempengaruhi berat produk akhir yang dihasilkan. Semakin kering produk, maka kandungan air yang ada pada produk semakin rendah sehingga beratnya juga semakin rendah. Hutomo (1997) dalam penelitiannya mengemukakan bahwa terjadi penurunan berat teripang kering sekitar $96 \%$ dari berat awal (teripang segar). Shelley (1985) menyatakan bahwa rasio berat segar dan berat teripang kering adalah $20: 1$, atau prosentase berat kering teripang hanya sebesar $5 \%$.

\section{Mutu Teripang Kering}

Teripang kering yang dihasilkan dapat dilihat pada Gambar 1. Tekstur teripang kering sangat keras seperti batu, tidak dapat dipotong menggunakan pisau sehingga sebelum dikonsumsi umumnya konsumen merebusnya dahulu agar tekstur dagingnya kembali kenyal. Tekstur seperti ini menandakan bahwa kadar air dalam tubuh teripang jumlahnya minimal. Berdasarkan SNI 01-23462006, tekstur teripang dikatakan baik dengan nilai organoleptik 9 jika teksturnya keras padat, kompak dan liat. Warna teripang kering adalah hitam merata di seluruh permukaan tubuhnya. Warna seperti ini menandakan teripang kering memiliki kualitas yang bagus (Purcell, 2014). Jika terdapat bintik-bintik putih menandakan bahwa masih terdapat sisa kapur pada permukaan tubuhnya. Bekas sayatan pada teripang kering juga tidak terlihat. Menurut SNI 01-23462006, kenampakan teripang dikatakan baik dengan nilai organoleptik 9 jika bekas belahan tertutup baik, serat-serat dalam utuh dan kulit luar rapih/menarik. 
Tertutupnya bekas sayatan pada teripang kering hasil penelitian dikarenakan pada saat pengeluaran isi perut, sayatan yang dibuat hanya berukuran kecil (selebar $1 \mathrm{~cm}$ ), sehingga setelah proses pengeringan bekas sayatan tidak terlihat.

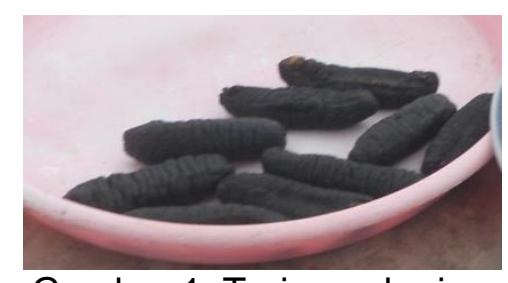

Gambar 1. Teripang kering

Menurut Purcell (2014), teripang kering dengan kualitas bagus dan tidak, dapat dilihat dari kenampakan secara visual selain melihat kandungan yang ada di dalamnya (Gambar 2). Kenampakan teripang kering yang tidak bagus dapat disebabkan oleh proses pengolahan yang tidak tepat. Hal ini tentu berdampak pada menurunnya harga jual teripang kering di pasar sehingga menimbulkan kerugian secara ekonomi.

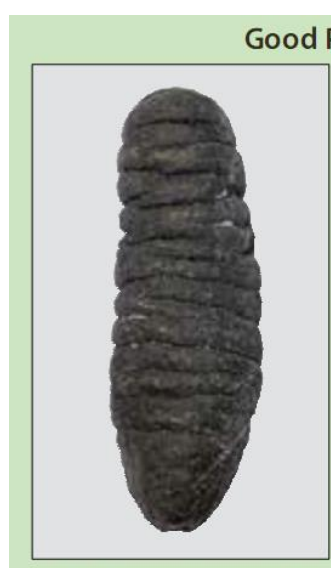

Dark colour, undamaged skin

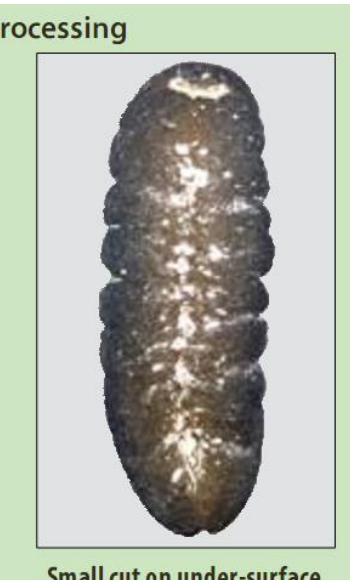

Small cut on under-surface

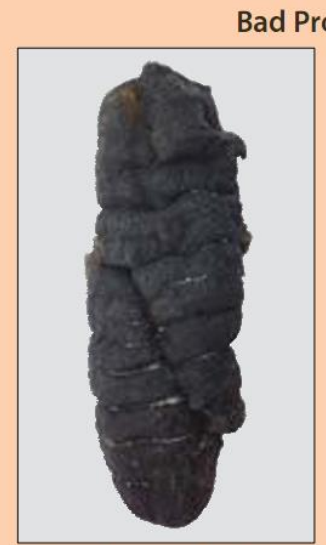

Cuts from poor handling

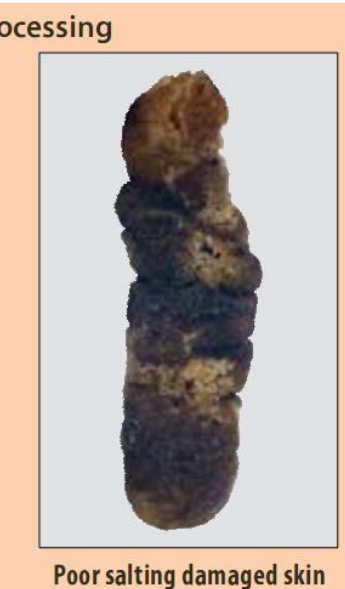

Poor salting damaged skin

Gambar 2. Perbandingan kenampakan teripang kering dengan metode pengolahan yang baik dan kurang baik (Purcell, 2014)

Mutu teripang kering lebih lanjut dapat ditentukan berdasarkan kandungan proksimatnya. Hasil analisis proksimat teripang kering dapat dilihat pada Tabel 1 .

Tabel 1. Hasil analisis proksimat teripang kering

\begin{tabular}{llcll}
\hline No & Parameter & Nilai $(\%)$ & Standar $(\%)^{\star}$ & Keterangan \\
\hline 1 & Kadar Air & 7,3 & Maks. 20 & Memenuhi standar \\
\hline 2 & Kadar Abu & 9,8 & Min. 7 & Memenuhi standar \\
\hline 3 & Kadar Protein & 79,59 & - & -
\end{tabular}

* Standar Nasional Indonesia (SNI) teripang kering (SPI-kan/02/29/1987) sesuai dengan Surat Keputusan Menteri Pertanian No.701/Kpts/TP.830/10/1987 tentang Penetapan Standar Mutu Hasil Perikanan (Ibrahim, 2011)

Tabel 1 menunjukkan bahwa teripang kering hasil penelitian telah memenuhi standar yang ditetapkan untuk produk teripang kering melalui SPIkan/02/29/1987. Kadar air teripang kering lebih rendah dari batas maksimal yang ditetapkan. Hal ini menunjukkan bahwa produk teripang kering memiliki kualitas 
yang baik. Rendahnya kadar air akan berdampak pada lamanya daya tahan teripang selama penyimpanan. Semakin kering suatu produk, maka daya tahannya akan semakin lama (Herliany, 2011). Kadar air juga mempengaruhi tekstur produk akhir yang dihasilkan. Tekstur produk teripang kering yang diinginkan menurut SNI 01-2346-2006 adalah keras padat, kompak dan liat dengan nilai organoleptik 9. Apabila kadar air terlalu tinggi, maka tekstur teripang kering kering menjadi lembek dan tidak kompak sehingga mempengaruhi penerimaan konsumen terhadap produk tersebut. Apabila dibandingkan dengan penelitian Hutomo (1997) yang menghasilkan teripang kering dengan kadar air sebesar $17,9 \%$, maka teripang kering hasil penelitian memiliki kualitas yang lebih baik. Perbedaan ini diduga disebabkan oleh perbedaan proses pengolahan serta komposisi bahan baku yang digunakan. Tetapi bila dibandingkan dengan penelitian Inayah $d k k$. (2012), kadar air teripang kering hasil penelitian iini tidak berbeda dengan hasil penelitian Inayah $d k k$. (2012) yang menghasilkan teripang kering dengan kadar air sebesar 7,773\%.

Kadar abu teripang kering hasil penelitian telah memenuhi standar yang ditetapkan oleh SNI yaitu minimal 7\%. Apabila dibandingkan dengan penelitian Hutomo (1997) dimana kadar abu teripangnya mencapai 16,8\%, maka kadar abu teripang kering hasil penelitian lebih rendah. Semakin tinggi kandungan abu yang terkandung dalam suatu bahan pangan maka kandungan mineral yang dihasilkan semakin banyak (Herniawan, 2010). Menurut Kustiariyah (2007), teripang mengandung zat-zat mineral seperti khromium, ferum, kadmium, mangan, nikel, kobalt dan seng. Nofrini (1993) menambahkan bahwa kandungan mineral pada teripang berupa fosfor, magnesium, kalsium, yodium, besi dan tembaga.

Kadar protein teripang hasil penelitian $(79,59 \%)$ lebih tinggi dari kadar protein teripang kering yang dihasilkan oleh Hutomo (1997) yaitu 56,62\% dan Kustiariyah (2006), yaitu 34,13\%. Teripang merupakan produk yang mengandung protein tinggi, sebagaimana produk perikanan lainnya. Protein merupakan suatu zat makanan yang sangat penting bagi tubuh karena berfungsi sebagai sumber energi, zat pembangun dan pengatur (Purnomo dan Adiono, 1988).

\section{KESIMPULAN}

\section{Kesimpulan}

Pengolahan teripang kering meliputi beberapa tahap yaitu pengeluaran isi perut, pencucian, perebusan sebanyak 3 kali, dan pengeringan. Berdasarkan analisis proksimat, teripang kering telah memenuhi Standar Nasional Indonesia untuk teripang kering dengan nilai kadar air sebesar 7,3\%, kadar abu 9,8\% dan kadar protein $79,59 \%$.

\section{Saran}

Untuk menentukan mutu teripang kering secara akurat, perlu dikaji lebih mendalam mengenai keseluruhan parameter mutu yang disyaratkan oleh Standar Nasional Indonesia seperti parameter organoleptik.

\section{DAFTAR PUSTAKA}


Adawiyah, R. 2007. Pengolahan dan pengawetan ikan. Jakarta : Bumi Aksara.

Brown, EO., ML Perez, LR Garces, RJ Ragaza, RA Bassig and EC Zagaroza. 2010. Value Chain Analysis for Sea Cucumber in Philippines. Studies and Reviews 2120. The WorldFish Center, Penang, Malaysia. 44pp.

Duan X, Zhang M, Mujumdar AS. 2007. Study on a combination drying technique of sea cucumber. Drying Technology 25 (12) : 2011-2019.

Faraouk, AE., Ghouse FAH, Ridzwan BH. 2007. New Bacterial Species Isolated from Malaysian Sea Cucumbers with Optimized Secreted Antibacterial Activity. American Journal of Biochemistry and Biotechnology. 3 (2) : 60 65.

Hadiwiyoto, S. 1993. Teknologi Pengolahan Hasil Perikanan. Jilid I. Liberty. Yogyakarta

Herliany, NE. 2011. Aplikasi Kappa karaginan dari rumput laut Kappaphycus alavarezi sebagai edible coating pada udang kupas rebus. Tesis. Sekolah Pascasarjana. Institut Pertanian Bogor. Bogor.

Herniawan. 2010. Pengaruh metode pengeringan terhadap mutu dan sifat fisikakimiatepung kasava terfermentasi. Skripsi. Fakultas Teknologi Pertanian. Institut Pertanian Bogor. Bogor.

Hutomo H. 1997. Mempelajari Penyimpanan Produk Teripang Kering (Holothuria scabra) dalam Berbagai Kemasan Plastik dan Pendugaan Umur Simpannya. Skripsi. Fakultas Perikanan dan IImu Kelautan, Institut Pertanian Bogor. Bogor.

Ibrahim, M. 2011. Peningkatan Mutu Teripang Kering. http://academiaedu.com/2011/04/teripang.html. Diakses Tanggal 08 April 2016.

Inayah, N., Rachmawati N., Tri K A. 2012. Uji Toksisitas Dan Identifikasi Awal Golongan Senyawa Aktif Ekstrak Etanol Dan N-Heksana Teripang Pasir (Holothuria scabra) Kering Pantai Kenjeran Surabaya. Alchemy. Vol. 2 (1) : 92-100.

Kustiariyah. 2007. Teripang Sebagai Sumber Pangan dan Bioaktif. Buletin Teknologi Hasil Perikanan. Vol X (1) : 1-8.

Kustiariyah. 2006. Isolasi, karakterisasi dan uji aktivitas biologis senyawa steroid dari teripang sebagai aprodisiaka alami. Tesis. Sekolah Pascasarjana. Institut Pertanian Bogor. Bogor.

Nofrini. 1993. Analisa usaha pengolahan teripang asap di Kecamatan Padang Cermin Kabupaten Lampung Selatan Propinsi Lampung. Skripsi. Fakultas Perikanan, Institut Pertanian Bogor. Bogor.

Purcell, S. W. 2014. Processing sea cucumbers into bêche-de-mer: A manual for Pacific Island fishers. Southern Cross University, Lismore, and the Secretariat of the Pacific Community, Noumea. $44 \mathrm{pp}$.

Purnomo, H. dan Adiono. 1988. Ilmu Pangan. Ditjen Pendidikan Tinggi Departemen P dan K. Jakarta.

Sasongko B. 2015. Kajian pengolahan dan mutu teripang asap. Skripsi. Program Studi IImu Kelautan, Fakultas Pertanian, Universitas Bengkulu. Bengkulu.

Shelley, CC. 1985. Growth of Actinopuga echinities and Holothuria scabra (Holothuroidea : Echinodermata) and their fisheries potential (as beche-demer) in Papua New Guinea. In Conad, C. 1990. The fishery resources of Pacific Island Countries. FAO. Technical Paper. Food and AgricultureOrganization. Rome.

(SNI) Standar Nasional Indonesia 01-2346-2006. Penentuan Uji Organoleptik. Jakarta :Dewan Standarisasi Nasional. 
(SNI) Standar Nasional Indonesia 01-2356-1991. Penentuan Kadar Air. Jakarta : Dewan Standarisasi Nasional.

(SNI) Standar Nasional Indonesia 01-2354-1991. Penentuan Kadar Abu. Jakarta : Dewan Standarisasi Nasional.

(SNI) Standar Nasional Indonesia 01-2365-1991. Penentuan Kadar Protein. Jakarta :Dewan Standarisasi Nasional.

Sofia, E. 1992. Pengaruh beberapa enzim proteolitik terhadap mutu dan kandungan teripang pasir (Holothuria scabra) asap. Skripsi. Fakultas Perikanan dan Ilmu Kelautan, Institut Pertanian Bogor. Bogor.

Subaldo, MC. 2011. Cleaning, Drying and Marketing Practices of Sea Cucumber in Davao Del Sur, Phillippines. JPAIR Multidisciplinary Journal. Vol $6: 117$ 126.

Sudrajat, Y. 2002. Teknik penghilangan lapisan kapur pada teripang pasir menggunakan enzim papain. Buletin Teknik Pertanian Vol. 7 (2) : 41-43.

Tanikawa. 1971. Marine Products in Japan. Koseisha-Koseikaku Co., Tokyo.

Wibowo, S dan Yunizal. 1997. Teknologi Penanganan dan Pengolahan Teripang (Holothuroidea). Jakarta : IPPL Slipi.

Winarmo, F.G., S. Fardiaz, dan D. Fardiaz 1980. Pengantar Teknologi Pangan. Gramedia. Jakarta. 